\title{
GMR
}

\section{First record of soybean stem fly Melanagromyza sojae (Diptera: Agromyzidae) in Paraguay confirmed by molecular evidence}

\author{
J.V.C. Guedes ${ }^{1}$, J.A. Arnemann ${ }^{1}$, L.E. Curioletti ${ }^{1}$, L.M. Burtet ${ }^{1}$, \\ M.L. Ramírez-Paredes ${ }^{2}$, D. Noschang ${ }^{3}$, F. Irala de Oliveira ${ }^{4}$ and W.T. Tay ${ }^{5}$ \\ ${ }^{1}$ Departamento de Defesa Fitossanitária, Universidade Federal de Santa Maria, \\ Santa Maria, RS, Brasil \\ ${ }^{2}$ Facultad de Ciencias Agropecuarias - Hohenau, \\ Universidad Católica "Nuestra Señora de la Asunción”, Campus Itapúa, Paraguay \\ ${ }^{3}$ Solum Paraguay, Mariscal, Lopez 3811, Dr Morra-Edificio Mcal Lopez Center, \\ Asunción, Paraguay \\ ${ }^{4}$ Syngenta, Calle Emilio Bobadilla Cáceres, Country Club, Hernandarias, \\ Alto Paraná, Paraguay \\ ${ }^{5}$ Commonwealth Scientific and Industrial Research Organisation - CSIRO, \\ Black Mountain Laboratories, Canberra, ACT, Australia \\ Corresponding author: J.A. Arnemann \\ E-mail: jonasarnemann@gmail.com
}

Genet. Mol. Res. 16 (3): gmr16039707

Received April 24, 2017

Accepted July 21, 2017

Published August 17, 2017

DOI http://dx.doi.org/10.4238/gmr16039707

Copyright (C) 2017 The Authors. This is an open-access article distributed under the terms of the Creative Commons Attribution ShareAlike (CC BY-SA) 4.0 License.

ABSTRACT. We provided the first scientific record of Melanagromyza sojae (Zehntner, 1900), through molecular characterization of partial mtDNA COI gene, that confirms the occurrence of this pest in Paraguay. Previously reported in Brazil, an outbreak of larvae of M. sojae known as the soybean stem fly (SSF) that belongs to the family Agromyzidae, was also noted in soybean fields from the Canindeyú, Alto Paraná and Itapúa Departments in Paraguay. This pest is highly polyphagous, attacking various host plant species from the family Fabaceae, such as soybean and other beans. The implications of SSF detection in 
Paraguay are discussed in relation to the current soybean cultivation practices from this agriculturally important South American region, including Brazil.

Key words: Soybean stalk fly; Biosecurity; mtDNA COI

\section{INTRODUCTION}

The agriculturally important Agromizidae fly Melanagromyza sojae has been reported in diverse global regions (Dempewolf, 2004) and is regarded as one of the most important pests in soybean fields in parts of Russia (Strakhova et al., 2013), in Asia [e.g., China (Wang and Gai, 2001); India and Nepal (Thapa, 2012)], in parts of South East Asia [e.g., Indonesia (Van Den Berg et al., 1995)], and in northern Australia (Shepard et al., 1983). In Australia, its potential as a significant soybean pest insect was realized with the first major outbreak reported in the tropical north Queensland region of Mackay in 2009, followed by a larger outbreak in the Casino region of northern New South Wales, and resulted in significant damage to Australia's subtropical coastal soybean crops in 2013 (Brier and Charleston, 2013).

M. sojae was previously identified as an important biosecurity pest for Brazil (Hirose and Moscardi, 2012). In South America, the genus Melanagromyza was first recorded in regions of Rio Grande do Sul State in southern Brazil, including Passo Fundo in 1983 (Gassen and Schneider, 1985) and São Francisco de Assis in 2009 (Link et al., 2009). Melanagromyza spp was also reported during the 2014/15 growing season around the southern region of Paraguay (Benítez-Díaz, 2015). In southern Brazil second soybean growing season of 2015, flies belonging to the Melanagromyza genus were reported in soybean fields from both Santa Catarina and Rio Grande do Sul states (Guedes et al., 2015). Arnemann et al. (2016a,b) subsequently confirmed the presence of M. sojae in soybean fields in Brazil via morphological and molecular characterization, and developed molecular markers based on the mitochondrial DNA partial cytochrome oxidase I (mtDNA COI) gene to facilitate with its species identification.

Reports indicated that soybean stem fly (SSF) can infest $100 \%$ of soybean plants and tunnelled up to $70 \%$ of stem length (Singh and Singh, 1990, 1992). SSF larvae damage the soybean stem, thereby impacting plant growth leading to reduced soybean yield (Talekar, 1989). Although suspected, there has been no confirmation of its presence in Paraguay to-date. In this study, specimens collected from four soybean fields in Paraguay were identified as M. sojae by combining both larval feeding behavior on host plants and molecular comparison of the partial mtDNA COI gene region, thereby confirming its occurrence in Paraguay soybean fields.

\section{MATERIAL AND METHODS}

\section{Samples}

A total of 23 fly larvae were collected from plants from soybean fields located in Corpus Christi (Departamento Canindeyú), San Alberto (Departamento Alto Paraná), Santa Rita (Departamento Alto Paraná) and Pirapó (Departamento Itapúa), Paraguay (Table 1 and Figure 1), during the cropping season of 2015/16. The insects were sent to Laboratório de Manejo Integrado de Pragas of Universidade Federal de Santa Maria (LabMIP-UFSM), Santa Maria, RS, Brazil, for molecular characterization and species confirmation.

Genetics and Molecular Research 16 (3): gmr16039707 
Table 1. Collection sites, mtDNA COI GenBank accession Nos. and GenBank haplotype locus ID of Melanogromyza sojae specimens from Paraguay.

\begin{tabular}{|c|c|c|c|c|}
\hline Sample ID & City & Departament & Accession No. & Haplotype locus \\
\hline 1 & San Alberto & Alto Paraná & KT821473 & Msoj-COI-01 \\
\hline 2 & San Alberto & Alto Paraná & KT821481 & Msoj-COI-03 \\
\hline 3 & San Alberto & Alto Paraná & MF441480 & Msoj-COI-11 \\
\hline 4 & San Alberto & Alto Paraná & MF441481 & Msoj-COI-12 \\
\hline 5 & San Alberto & Alto Paraná & MF441485 & \begin{tabular}{|l} 
Msoj-COI-16 \\
\end{tabular} \\
\hline 6 & Santa Rita & Alto Paraná & KT821473 & Msoj-COI-01 \\
\hline 7 & Santa Rita & Alto Paraná & KT821473 & Msoj-COI-01 \\
\hline 8 & Santa Rita & Alto Paraná & KT821496 & Msoj-COI-09 \\
\hline 9 & Santa Rita & Alto Paraná & MF441483 & Msoj-COI-14 \\
\hline 10 & Santa Rita & Alto Paraná & MF441484 & Msoj-COI-15 \\
\hline 11 & Corpus Christi & Canindeyú & KT821473 & Msoj-COI-01 \\
\hline 12 & Corpus Christi & Canindeyú & KT821473 & Msoj-COI-01 \\
\hline 13 & Corpus Christi & Canindeyú & KT821494 & Msoj-COI-07 \\
\hline 14 & Corpus Christi & Canindeyú & MF441482 & Msoj-COI-13 \\
\hline 15 & Corpus Christi & Canindeyú & MF441482 & Msoj-COI-13 \\
\hline 16 & Pirapó & Itapúa & KT821473 & Msoj-COI-01 \\
\hline 17 & Pirapó & Itapúa & KT821481 & Msoj-COI-02 \\
\hline 18 & Pirapó & Itapúa & KT821481 & Msoj-COI-02 \\
\hline 19 & Pirapó & Itapúa & KT821495 & Msoj-COI-08 \\
\hline 20 & Pirapó & Itapúa & KT821496 & Msoj-COI-09 \\
\hline 21 & Pirapó & Itapúa & MF441486 & Msoj-COI-17 ${ }^{\dagger}$ \\
\hline 22 & Pirapó & Itapúa & MF441487 & Msoj-COI-18 \\
\hline 23 & Pirapó & Itapúa & MF441482 & Msoj-COI-13 \\
\hline
\end{tabular}

All samples were collected in December 2015. New identified haplotypes are indicated by ' $\dagger$ '.
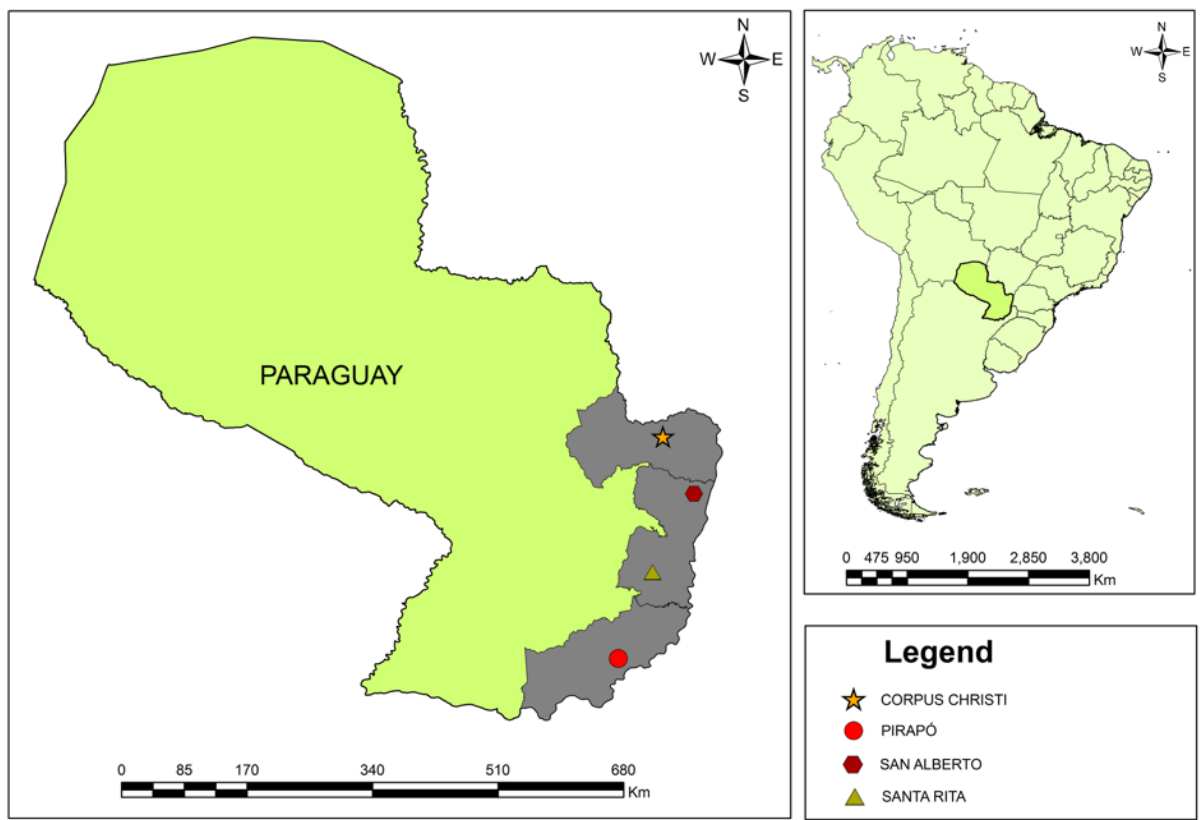

Figure 1. A map of sampling sites in Paraguay from which suspected Melanogromyza sojae were collected. The soybean fields were located in Corpus Christi (Departamento Canindeyú), San Alberto (Departamento Alto Paraná), Santa Rita (Departamento Alto Paraná), and Pirapó (Departamento Itapúa), Paraguay.

Genetics and Molecular Research 16 (3): gmr16039707 


\section{Total genomic DNA (gDNA) extraction}

Individual specimens were washed three times in $1000 \mu \mathrm{L}$ of fresh $(99.9 \%)$ ethanol prior to gDNA extraction. Total gDNA from all specimens was extracted from whole larval body using Qiagen DNeasy Blood and Tissue DNA Extraction Kit according to manufacturer instructions. Final elution volume for individual gDNA samples was in $35 \mu \mathrm{L}$ Qiagen buffer $\mathrm{AE}$, with gDNA quality ascertained by $1.5 \%$ agarose gel visualization, and concentration quantified using Qubit 2.0 Fluorometer (Invitrogen).

\section{PCR amplification and sequencing of the partial mtDNA COI gene}

We used SSF-specific partial mtDNA COI gene PCR primers (SSF-COI-F01: 5'-GAC AATGATTATTTTCGACAAAT-3'; SSF-COI-R01: 5'-GTAAAATAAGCTCGTGTATCTACA TC-3') developed by Arnemann et al. (2016b) for molecular characterization of the suspected SSF individuals. PCR conditions for the mtDNA COI primer pairs were as previously reported (Arnemann et al., 2016b). The PCR amplicons were sent to Helixxa, Paulínia-SP-Brazil, for sequencing.

\section{Sequence analysis and molecular characterization of the mtDNA COI gene}

The programs Pregap and Gap4 within the Staden package (Staden et al., 2000) were used for editing the sequences. Sequence alignments of all mtCOI haplotypes was carried out using Geneious R9 (Biomatters Ltd., New Zealand). We checked for potential presence of premature stop codons by translating the partial mtCOI sequences into protein sequences by selecting the invertebrate genetic code 5 for amino acid translation. Nucleotide distances (uncorrected P-distance) between specimens from Paraguay and all previously reported mtDNA COI haplotypes from Brazil and Australia (Arnemann et al., 2016b) were calculated in MEGA (Tamura et al., 2013), and maximum likelihood phylogeny was inferred using the web-based program PhyML (Guindon et al., 2010) using the automatic model selection option followed by 1000 bootstrap replications to estimate node confidence. Selection of out-group species Ophiomyia quinta (EF104665) and Ophiomyia nasuta (EF104661) for the phylogenetic analysis was based on the study of Scheffer et al. (2007).

\section{RESULTS}

Our results, based on molecular characterization of the mtDNA COI partial gene, provided the first record of M. sojae in Paraguay, and represented the first confirmation of the occurrence of this pest in soybean fields from the Canindeyú, Alto Paraná and Itapúa Departments in Paraguay. A 906-bp fragment of the mtDNA COI gene was PCR amplified using the SSF-specific mtDNA COI primers from 23 suspected individuals from Paraguay (Table 1). Post-sequencing trimming of the sequenced amplicons resulted in 740-bp partial mtDNA COI contigs in all samples. The low estimates of evolutionary divergence between $M$. sojae sequences were as expected at the intra-species level (e.g., Scheffer, 2000; Arnemann et al., 2016b) and ranged from 0 to $0.012 \%$ ( \pm 0.001-0.004 SE). The evolutionary divergence between SSF haplotypes from Paraguay and Brazil was $0.005 \%$, and between Paraguay and Australia was $0.003 \%$. All mtDNA COI sequences generated from this study have

Genetics and Molecular Research 16 (3): gmr16039707 
been submitted to GenBank (accession Nos.: MF441480- MF441487). The inferred partial mtCOI phylogeny (Figure 2) suggested a basal position for M. sojae as compared with other Agromyzidae species.

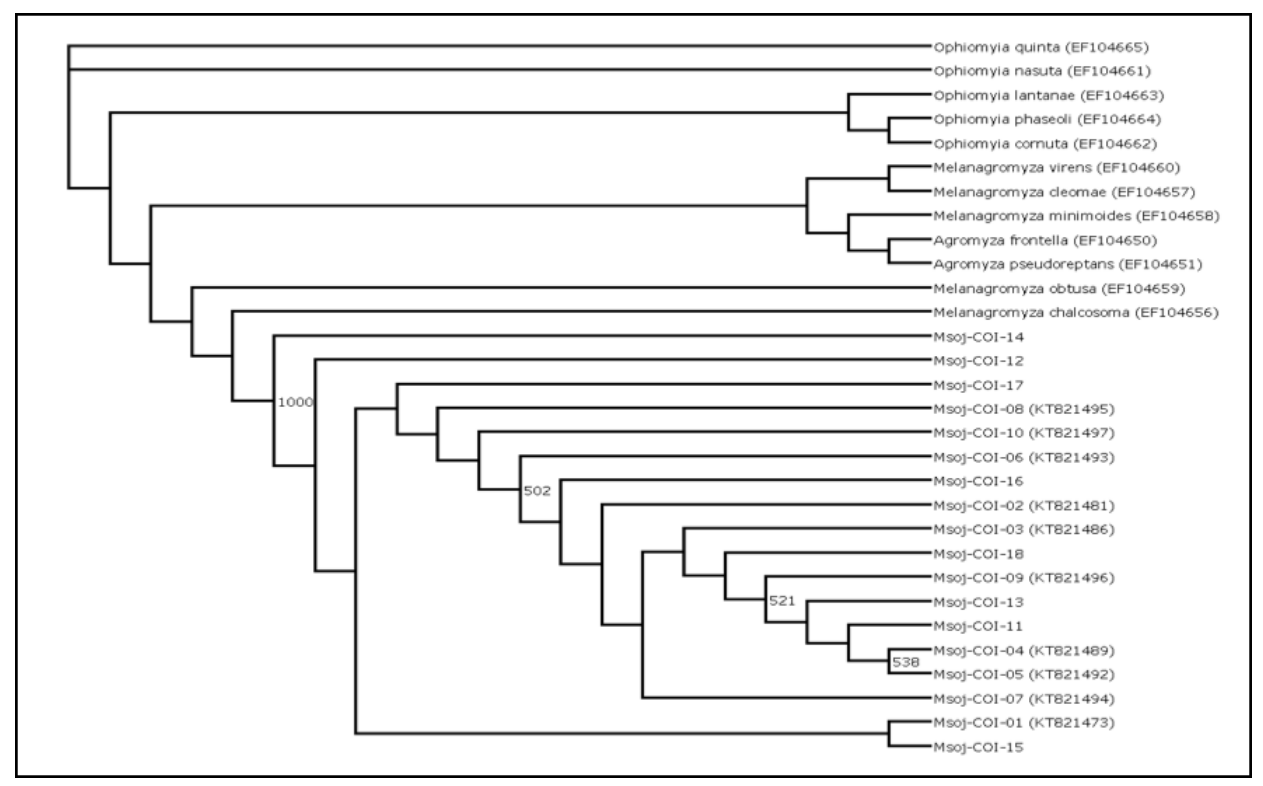

Figure 2. Maximum likelihood (ML) phylogeny analysis using PhyML (Guindon et al., 2010) of Agromyzidae species and Melanagromyza sojae haplotypes (substitution model: GTR+G+I; 7483.12450 (AIC); Gamma shape parameter: 1.075 , proportion of invariable sites: 0.608 ), based on $684 \mathrm{bp}$ partial mtCOI gene. The outgroup is Ophiomyia quinta (EF104665) and Ophiomyia nasuta (EF104661) (Scheffer et al., 2007). Nodes with bootstrap values of $>50 \%$ are shown. The GenBank accession Nos. for all samples used are provided.

\section{DISCUSSION}

From the 23 M. sojae specimens collected from Paraguay, we identified a total of 15 haplotypes, eight of which were novel haplotypes, 6 were identical to previously reported Brazil haplotypes (i.e., 'Msoj-COI-01', 'Msoj-COI-02', 'Msoj-COI-03', 'Msoj-COI-07', 'Msoj-COI-08', 'Msoj-COI-09'; Arnemann et al., 2016b), and one with Australia (haplotype 'Msoj-COI-02' (Arnemann et al., 2016b), individuals 17 and 18, from Pirapó, Table 1).

Our study enabled a preliminary genetic diversity survey of SSF in Paraguay and provided the first insights into potential patterns of biological incursion in the Cone Sul region of South America. Efforts must now be made to re-examine biosecurity protocols relating to phytosanitary practices of agricultural and horticultural commodities that are entering Paraguay and Brazil. Studies to date, including that of Arnemann et al. (2016a,b) have surveyed only limited populations of SSF in both Brazil and Paraguay, thereby limiting detailed understanding the genetic diversity of SSF populations in the Cone Sul regions of South America. While detection of unique haplotypes that are not shared between Paraguay and Brazil points to a potential hypothesis of multiple independent incursions of SSF in South America, increasing sampling sizes and the molecular characterization of multiple DNA gene regions will be needed to better test this hypothesis. The potential of establishment of $M$. 
sojae in the North and across the South American continents is unknown. However, M. sojae has been detected across diverse eco-climatic zones (Dempewolf, 2004) and it would suggest that it has the potential to also establish successful populations throughout the New World. Understanding the potential distributional range of $M$. sojae may benefit from pre-emptive population modelling to assist with biosecurity preparedness, as has been carried out for $H$. armigera (Kriticos et al., 2015).

The Paraguay soybean area is estimated to be 3.82 million hectares, with 0.56 million hectares in the second growing season (off-season), with estimated grain production of 8.8 million tons, resulting in Paraguay being the 6th worldwide highest soybean production country (Capeco, 2016), and contributing an approximate US\$2.93 billion to the country economy. Our study has confirmed the presence of SSF in the three most important Departments for soybean production in Paraguay (i.e., Canindeyú Department, Alto Paraná Department, Itapúa Department). This correspond to $65.8 \%$ of soybean cultivated area in Paraguay (Peckholtz, 2015). These Departments are located at the eastern region of Paraguay, being the closest region to Santa Catarina and Rio Grande do Sul States, both of which have significant soybean growing activities and are the regions where SSF was also identified (Arnemann et al., 2016b). Gene flow patterns of SSF populations between Brazil and Paraguay will be needed to better understand the extend of population boundaries, and which will be crucial for the development of either regional or country-specific pest management practices.

The confirmation of $M$. sojae occurrence in Paraguay is the first step towards developing effective integrated pest management (IPM) and resistance pest management (RPM) strategies. Agronomists and soybean growers from Paraguay mentioned that in the 2015/16 crop season, the SSF incidence on early soybean sowing season was moderate and restricted to first sown fields. However, on the late growing season, the incidence was high, reaching up to $100 \%$ of attacked plants in most fields. Occurrence and distribution of M. sojae in soybeans fields of Paraguay during two seasons suggested that the insect population to be substantially established in the country, especially because the incidence of Agromyzidae flies was mentioned in the last decade on soybean on Paraguay. Despite this, overall yield losses due to SSF damage in Brazil and Paraguay remained poorly understood. Similarly, ecological knowledge of SSF in the New World, including native beneficial insects that target this insect pest, will be needed if effective IPM and RPM were to be developed.

Across Old World regions, where SSF is endemic and represents an economically important pest for the soybean crop, important control measures have involved the use of resistant cultivars and sowing outside population peaks. The use of endemic beneficial insects, such as parasitoids, has been mentioned as one of the important biological control strategies (e.g., Talekar, 1990; Van Den Berg, 1995). The evaluation and use of insecticides applied to seed or foliar sprays have also been reported (e.g., Adak et al., 2012; Jadhav et al., 2013). In Paraguay, the use of seed treatments with insecticides belonging to the neonicotinoids, phenyl pyrazole, carbamates group and foliar pulverization with pyrethroids, avermectin, neonicotinoids, organophosphorus, diamides, carbamates and IGRs insecticides are currently the main strategy for controlling other major insect pests of soybean, including caterpillars (e.g., Chrysodeixis includens, Helicoverpa spp (i.e., H. zea; and potentially H. armigera known to be also present in Paraguay; Arnemann et al., 2016c) and stink bugs (e.g., Euschistus heros, Piezodorus guildinii) and beetles (e.g., Sternechus subsignatus). However, given the high incidence of SSF in the second soybean crop of 2015/16, and despite the intense use of such chemicals, it suggested that chemical control for the management of SSF in Paraguay has

Genetics and Molecular Research 16 (3): gmr16039707 
not achieved its desired outcome. This highlights the need to re-evaluate the effectiveness of these pesticides and insecticide resistance profiles of SSF, and potential benefits of adopting alternative new genetic technologies such as BT-GMOs crop to assist with SSF control.

\section{Conflicts of interest}

The authors declare no conflict of interest.

\section{ACKNOWLEDGMENTS}

The authors wish to thank Gustavo Ugalde for assisting with samplings and Maicon Machado for the preparation of Figure 1. W.T. Tay was supported by CSIRO Health and Biosecurity (\#R-8681-1).

\section{REFERENCES}

Adak T, Kumar J, Dey D, Shakil NA, et al. (2012). Residue and bio-efficacy evaluation of controlled release formulations of imidacloprid against pests in soybean (Glycine max). J. Environ. Sci. Health B 47: 226-231. https://doi.org/10.10 $\underline{\text { 80/03601234.2012.634368 }}$

Arnemann JA, Walsh TK, Gordon KH, Brier H, et al. (2016a). Complete mitochondrial genome of the soybean stem fly Melanagromyza sojae (Diptera: Agromyzidae). Mitochondrial DNA A. DNA Mapp. Seq. Anal. 27: 4534-4535. https://doi.org/10.3109/19401736.2015.1101550

Arnemann JA, Tay WT, Walsh T, Brier H, et al. (2016b). Soybean Stem Fly, Melanagromyza sojae (Diptera: Agromyzidae), in the New World: detection of high genetic diversity from soybean fields in Brazil. Genet. Mol. Res. 15: gmr.15028610.

Arnemann JA, James WJ, Walsh TK, Guedes JVC, et al. (2016c). Mitochondrial DNA COI characterization of Helicoverpa armigera (Lepidoptera: Noctuidae) from Paraguay and Uruguay. Genet. Mol. Res. 15: gmr.15028292.

Benítez-Díaz EA (2015). Melanagromyza sp. (Diptera: Agromyzidae) mosca barrenadora del tallo en soja. Circular Técnica n. 7, SENAVE, 1pp. Available at [http://www.senave.gov.py/docs/circular/Circular-Tecnica-N7Melanagromyza-2015.pdf]. Acessed 15 July 2016.

Brier H and Charleston K (2013). Soybean stem fly outbreak in soybean crops. The Beatsheet. April 10, 2013. Available at [http:/thebeatsheet.com.au/crops/pulses/soybeans/soybean-stem-fly-outbreak-in-soybean-crops/]. Accessed 15 July 2016.

Capeco (2016). Área de Siembra, Producción y Rendimiento. [cited 01 February 2016]. In: CAPECO [Internet]. Assuncion: CAPECO 2016 Available at [http://capeco.org.py/area-de-siembra-produccion-y-rendimiento/].

Dempewolf M (2004). Arthropods of economic importance: Agromyzidae of the World. ETI-Information Services; Wokingham; UK (unpaginated).

Gassen DK and Schneider S (1985). Ocorrência de Melanagromyza sp. (Dip. Agromizidae) danificando soja no sul do Brasil. In: Reunião De Pesquisa da Soja da Região Sul, 13, 1985, Porto Alegre. Soja: resultados de pesquisa 1984-85. EMBRAPA-CNPT, Passo Fundo, 108-109.

Guedes JVC, Curioletti LE, Beche M and Arnemann JA (2015). Mosca-da-haste da soja no Brasil. Cultivar Grandes Culturas. Outubro: 28-30.

Guindon S, Dufayard JF, Lefort V, Anisimova M, et al. (2010). New algorithms and methods to estimate maximumlikelihood phylogenies: assessing the performance of PhyML 3.0. Syst. Biol. 59: 307-321. https://doi.org/10.1093/ sysbio/syq010

Hirose E and Moscardi F (2012). Insetos de outras regiões do mundo. IN: EMBRAPA-Soja: manejo integrado de insetos e outros artrópodes-praga. Brasília, DF, Embrapa.

Jadhav SN, Krishna-Naik L, Giraddi RS, Babalad HB, et al. (2013). Development of management strategies against stem fly Melanagromyza sojae (Zehntner) in soybean ecosystem. J. Exp. Zool. 16: 245-252.

Kriticos DJ, Ota N, Hutchison WD, Beddow J, et al. (2015). The potential distribution of invading Helicoverpa armigera in North America: is it just a matter of time? PLoS One 10: 7: e0133224.

Link D, Hatschbach M and Link FM (2009). Mosca da haste da soja: ocorrência e danos. In: XXXVII Reunião de pesquisa de soja da região Sul, Porto Alegre. Available at [http://www.ufrgs.br/agronomia/materiais/XXXVIIRPSSul.pdf]. Accessed July 15, 2016.

Genetics and Molecular Research 16 (3): gmr16039707 
Peckholtz F (2015). Estimación por Análisis Geo-Espacial de Cobertura del Cultivo de: Región Oriental del Paraguay. 2015 April 27 [cited 20 July 2016]. In: CAPECO [Internet]. Assuncion: CAPECO 2015 Available at [http://capeco. org.py/wp-content/uploads/2015/06/estimacion-de-produccion-soja-campana-2014-2015-inbio-capeco.pdf].

Scheffer SJ (2000). Molecular evidence of cryptic species within the Liriomyza huidobrensis (Diptera: Agromyzidae). J. Econ. Entomol. 93: 1146-1151. https://doi.org/10.1603/0022-0493-93.4.1146

Scheffer SJ, Winkler IS and Wiegmann BM (2007). Phylogenetic relationships within the leaf-mining flies (Diptera: Agromyzidae) inferred from sequence data from multiple genes. Mol. Phylogenet. Evol. 42: 756-775. https://doi. org/10.1016/j.ympev.2006.12.018

Shepard M, Lawn RJ and Schneider MA (1983). Insects on Grain Legumes in Northern Australia: A Survey of Potential Pests and Their Enemies. University of Queensland Press. Australia, 81.

Singh KJ and Singh OP (1992). Influence of stem tunneling by the maggots of Melanagromyza sojae (Zehn.) on yield of soybean. J. Insect Sci. (Ludhiana) 5: 198-200.

Singh OP and Singh KJ (1990). Seasonal incidence and damage of Melanagromyza sojae (Zehnt.) on soybean. Indian J. Plant Prot. 18: 271-275.

Staden R, Beal KF and Bonfield JK (2000). The Staden package, 1998. Methods Mol. Biol. 132: 115-130.

Strakhova IS, Yefremova ZA, Tschirnhaus M and Yegorenkova EN (2013). The parasitoid complex (Hymenoptera, Eulophidae) of leafminer flies (Diptera, Agromyzidae) in the middle Volga Basin. Ent.Rev. 93: 865-873. https://doi. org $/ 10.1134 / \mathrm{S} 0013873813070087$

Talekar NS (1989). Characteristics of Melanagromyza sojae (Diptera: Agromyzidae) damage in soybean. J. Econ. Entomol. 82: $584-588$. https://doi.org/10.1093/jee/82.2.584

Talekar NS (1990). Agromyzid flies of food legumes in the tropics. Wiley Eastern, New Delhi, v. 297.

Tamura K, Stecher G, Peterson D, Filipski A, et al. (2013). MEGA6: Molecular evolutionary genetics analysis version 6.0. Mol. Biol. Evol. 30: 2725-2729. https://doi.org/10.1093/molbev/mst197

Thapa RB (2012). Redescription of Melanagromyza sojae (Zehntner) from India and Nepal. Nepalese J. Biosci. 2: 64-70.

Van Den Berg H, Ankasah D, Hassan K, Muhammad A, et al. (1995). Soybean stem fly, Melanagromyza sojae (Diptera: Agromyzidae), on Sumatra: Seasonal incidence and the role of parasitism. Int. J. Pest Manage. 41: 127-133. https:// doi.org/10.1080/09670879509371937

Wang J and Gai J (2001). Mixed inheritance model for resistance to agromyzid beanfly (Melanagromyza sojae Zehntner) in soybean. Euphytica 122: 9-18. https://doi.org/10.1023/A:1012649506212

Genetics and Molecular Research 16 (3): gmr16039707 